\title{
A Study on the Attitude and Purchase Intention of Consumer Regarding Green Electronics
}

\author{
Tushar Chhabra ${ }^{1} \mid$ Dr. Prachi Trivedi ${ }^{1}$ \\ ${ }^{1}$ Department of Marketing and Sales, Amity Business School
}

To Cite this Article

Tushar Chhabra and Dr. Prachi Trivedi, "A Study on the Attitude and Purchase Intention of Consumer Regarding Green Electronics", International Journal for Modern Trends in Science and Technology, Vol. 06, Issue 06, June 2020, pp.:191-203; https://doi.org/10.46501/IJMTST060635

\section{Article Info}

Received on 26-May-2020, Revised on 05-June-2020, Accepted on 13-June-2020, Published on 26-June-2020.

\section{ABSTRACT}

Green Electronics is a concept which is very significant playing an important role towards world's sustainable development. Markets are expanding and consumers are buying large volumes of goods, the manufacturing as well as usage designs are extensively polluting the world which we live in. The users, manufacturers and also the governments have perceived the price of this particular problem. The R\&D department of companies as well as the industries are working hard to evolve an eco-friendly product which would reduce the environmental damage. Products of the companies which can be reprocessed, and owns healthy discarding characteristics are called as green products. Electronics has created a trouble-free existence for humans. There are few elements in electric products which are injurious and bad to the natural environment and humans. This concept focuses on the removal of the poisonous and injurious chemical elements from the green electronics, and reprocessing the electronic gadgets in the end. This study aims to understand the concept of Green Product, Green Electronics and Consumer Behaviour towards it.

KEYWORDS: Green Electronics, Green Electronics Perception, Environmental Problems, Eco-friendly products.

Copyright (C) 2014-2020 International Journal for Modern Trends in Science and Technology

DOI: https://doi.org/10.46501/IJMTST060635

\section{INTRODUCTION}

Electronics has made life easier for us. We use them in our day-to-day lives. In today's world it is necessity for human being. But Certain material used in electric products are actually harmful and present a risk to the planet. To come over this situation, companies are using Green Electronics.

In today's market consumer is the king. Now consumers are well equipped with the knowledge. They know everything. They mostly prefer environment friendly products for the better future.

Consumer has now changed their decisions towards purchasing eco-friendly goods due to the growing awareness in the present Environmental matters. So, to grab a larger market share it is important for all the companies that they need to make a first move in order to have a First mover advantage.

Green consumption movement have been there for the longest time in the Developed. Countries and it has become very important for the Environment. Even Developing Countries are taking various measures towards developing Eco-friendly goods so that the goods which are produced are less harmful for the Environment. So many Developed and Developing Countries are 
adopting this consumption patter as-a pillar of Natural Development, for better tomorrow.

\section{BEFORE GOING ANY FURTHER FIRST WE SHOULD DISCUSS ABOUT:}

\section{GREEN PRODUCTS}

Green Products are those which causes no risk to environment and those which are manufactured through Green Technology. It is a sustainable product which is designed to reduce waste, recycle products at the end of their life, and minimize the environmental risk.

We can define green products by following measures:

- Energy efficient products.

- Water efficient products.

- Low emitting (low on hazardous emissions).

- Healthy and/or safe products.

- Recyclable and/or with recycled content products.

- Durable products.

- Biodegradable products.

- Renewable products.

- Reused or reusable products.

- Third party certified products.

- Locally manufactured products.

\section{Significance of Green Product and Innovation} Green product - Adopts by the firms:

Firms globally are commonly using Green Products and possibly the actual reason cited for that wide ranging adoption are as followed:

\section{a) Opportunities in Green product}

In this field first mover advantage plays a crucial role because when the demand of Green products rises, the firms which are already producing it, will enjoy the competitive advantage over the other companies. This helps the firms in strengthening its Goodwill.

\section{b) Government Pressure}

As Environmental degradation has become an issue of concern for the whole world. It has become a sensitive issue of decision-making factor for all the governments across the globe. The government is also promoting and pressurizing use of green technology. It is providing subsidies for implementation of green and clean technology to manufacturers and to consumers for purchasing green products.

\section{c) Competitive Pressure}

Adoption of green practices by the businesses will help a company to gain strategic advantage over its competitors in the industry. A point of ${ }^{\bullet}$ difference will be created if organizations are able to meet the needs and wants of the customers along with environmental benefits. It will create a unique selling proposition which will attract more customers to go for the goods and services in question. It will strengthen the position of the business in the industry.

\section{d) Social Responsibility}

Many companies are starting to recognise that they're members of society and consequently should act in an responsible way towards it. This results in environmental issues being integrated into the firm 's business culture.

\section{e) Cost or Profit Issues}

For addressing the cost or profit related issues Firms can use the Eco-friendly products i.e. Green products. Disposal of environmentally harmful products are really very expensive. Therefore firms can reduce the use of harmful material which directly result in cost saving as the work of disposing harmful products would be reduced.

\section{Green Marketing}

Green advertising is the advertising of eco-friendly goods \& services. This technique is becoming very popular as now people are becoming concerned about the environment and they are even willing to bear extra cost for the same for the better future.

It involves variety of different things like producing eco-friendly products that are less hazardous to the environment and can be recycled very easily, developing environment friendly business practices, using eco-friendly packaging, or perhaps focusing on marketing efforts that make people aware about the benefits of eco-friendly products.

This particular marketing type is little expensive, though it is equally rewarding as a result of growing need. For instance, items made locally in North America are likely to be costly compared to those made overseas utilizing affordable labour, though they've a significantly smaller carbon footprint since they do not need to fly throughout the world to be right here. For many customers as well as business proprietors, the environmental advantage outweighs the cost difference.

\section{Green Marketing Methods}

Beyond making an eco-friendly item, business people are able to do other things as a part of their green marketing and advertising efforts. The following could all be a part of an environmentally friendly advertising strategy:

Use electronic marketing instead of printed resources entirely. 
- Using eco-friendly less consuming power sources.

- Having a recycling program as well as conscientious waste disposal methods.

- For printing marketing materials using eco-friendly inks and papers.

- Taking various steps towards reducing environmental impact.

- Eco-friendly packaging should be used.

- Efficient Eco-friendly packing and shipping method should be used.

\section{What Is Green Electronics?}

Electronics has created a trouble-free existence for humans. There are few elements in electric products which are injurious and bad to the natural environment and humans. Green Electronics focuses on the removal of the poisonous and injurious chemical elements from the green electronics, and reprocessing the electronic gadgets in the end. Injurious chemicals present in the Electronics are Lead, Cadmium, Mercury, Polybrominated Diphenyl's Ethers (PBDE). As an example, coating of the cable is burnt to attain the copper which is inside of it releasing poisonous chemicals in the environment. 2 This particular activity of burning the cable to 3 . attain the copper deteriorates the environment by 4 . acid rain.

Several countries have legislated a statute to stop the use of poisonous chemicals such as Lead and other poisonous chemicals for the production of Electronic Products.

\section{Electronic Waste}

There are a large amount of electronic devices which are being manufactured and thrown away, a novel environmental issue has erupted named "Electronic Waste," or the obsolete electronics that are either not working or not wanted, have commenced to fill up the grounds at a very high speed. These Electronic gadgets contain injurious elements which would jeopardise the environment and the people living in surrounding areas.

Electronic Waste is nothing but abandoned, 1 . Incineration obsolete, faulty electronics or electronics which 2. Land filling are not useful. Products such as Personal 3. Recycling Computers, Televisions, cell phones, music players, Photostat copy machines, and fax machines are everyday electronic products.

According to the EPA (Environmental Protection Agency), nationally, an estimated 5 to 7 million tons of computers, televisions, stereos, cell phones, electronic appliances and toys, and other electronic gadgets become obsolete every year. Computer monitors and older television picture tubes contain an average of four pounds of lead.

\section{Electronic Waste: What's The Big Issue?}

From banking to the visitors signals on community streets, electric equipment can make our world comfortable and effective. But when these electronic devices break down or perhaps no longer provide the users' requirements, they become a part of probably the fastest growing part of our everyday strong waste stream - electronic waste product, generally described as e waste.

Often, appliances are tossed out with household garbage. However dangerous elements lead, cadmium and mercury for instance found in electronics may be dangerous when they're compressed at landfills. Televisions and CRT (Cathode Ray Tube) monitors possess an average of 4 pounds of lead. Probably the largest tool of cadmium in municipal waste product is actually rechargeable nickel cadmium (NiCad) power packs, generally used in laptops, cameras and cell phones.

\section{Hazards In E-Waste}

\section{Lead}

. Cadmium

Mercury

4. Hexavalent Chromium/Chromium VI

5. Barium

6. Beryllium

7. Toners

8. Phosphor and additives

\section{E-Waste Predictions}

Toxics link, a Delhi grounded company states that India produces $\$ 1.5$ billion worth of e-waste annually. Put simply, manufactures as well as assemblers produce around 1050 lots of electric scrap in a single year. Forty million PCs were obsolete in 2001 Only and approximately ten per cent had been recycled Electronics are actually a quickly growing an element of this waste stream.

Disposal Of Waste

E-waste can be disposed in three ways: 


\begin{tabular}{|c|l|}
\hline \multicolumn{2}{|c|}{ Categories of E-Waste as per European Council [1] } \\
\hline S. No. & \multicolumn{1}{c|}{ Categories } \\
\hline 1 & Large Household Appliances \\
\hline 2 & Small Household Appliances \\
\hline 3 & IT \& Telecommunication Equipment \\
\hline 4 & Consumer Equipment \\
\hline 5 & Industrial Tools \\
\hline 6 & Lighting Equipment \\
\hline 7 & Toys, Leisure \& Sports Equipment \\
\hline 8 & Medical Devices \\
\hline 9 & Monitoring \& Control Instruments \\
\hline 10 & Automatic Dispensers \\
\hline
\end{tabular}

\section{Green Electronics Council}

It was in the year 2005 that Green Electronics Council (GEC) was constituted. It is an organization with no motive for profit making which gets together to attain an environment in which only healthy Information Technology goods are planned, produced, and sold. Distinct kinds of certification is given by the Council such as Gold Certification, Bronze Certification and Silver Certification which represent the levels for corporate firms which produce environment friendly commodity. The Organization uses a specially designed assessment tool called as Electronic Product Environmental Assessment Tool (EPEAT) to grade the gadgets.

GEC promotes green computing and "envisions a world where green electronics is a cornerstone of a healthy and vibrant world". Dozens of groups work hard around the world to develop new environmental and electronics standards every day, where the Green Electronics Council is most engaged is the convergence of those two: Environmental Leadership Standards for Electronics that kick-started the successful EPEAT program.

\section{Role Of Society And Companies \\ Role of Society}

- Identify Durable Products

- Repair instead of Replace

- Buy Upgradeable Gear

\section{Role Of Companies}

- Material Innovation

- Recyclable Designs

\section{Recent Developments}

Presently, three proposals are under consideration which will considerably impact the style, disposal and manufacture of all kinds of electronic and electrical equipment:
Working papers for an electronic and electrical equipment directive (EEE).

Direction on restricting the use of some Hazardous substances in electronic and electrical equipment(ROHs)

Directive on waste out of electronic and electrical equipment (WEEE)

\section{Government Initiative in India}

\section{Ministry of Electronics and Information} Technology (MeitY) (Government of

India)Ministry of Information and Electronics Technology (MEITY) (Government of India) is running a programme which is designed to produce highly effective recognition in different levels of society to bring down the negative effect on environment as well as wellness arising out of the contaminating systems utilized in recycling e-waste in the unorganized industry. The charter for this particular programme is actually bringing in concert the triad of public, industry and government to adopt conscientious methods for sustainable electronics which is actually responsive to environmental requirements. This needs proactive policy development and mass deployment which would be the focus region.

In 2006, Ministry of Environment and forests released The National Environmental Policy (NEP) which aims to save the natural resources through recycling and reuse the waste as well as the old products and simultaneously reducing the waste disposal, therefore making awareness and encouraging people about using the waste as a resource. NEP also includes the provision for compilation of recyclable materials.

However, in India, as of now you will find no particular environmental regulations or laws for e waste management. As specified, in India nearly all of the recycling happens within the casual sector with a few formal recyclers, waste management businesses as well as investors currently entering the industry. So Role of Informal Sector remains important for the Government of India in value chain of e-waste due to its possibilities in generating employment.

\section{Consumer}

Consumer is the person who purchases goods or services for personal use. Consumer is the king. They can make decision whether to purchase the item or not without any restrictions. Consumer is the one whose decision might get affected by various marketing and advertisement. When someone goes to various store to buy the products like Cell Phones, Computers, Chocolates, etc they're making the choice as being the Customer. 
The consumer is the person who purchase goods and services that are produced and pays for them. As a result, Customer plays a very important role in the Chain Of Distribution. So in the lack of customer demand, producers would lack one of the major motivations to produce the product, as the product is no longer in demand so who would they sell to.

\section{Consumer buying behaviour}

Consumer Buying Behaviour is the sum total of Consumer's behaviours like intention, perception, choices and preference towards purchasing a product or service in the market.

A firm has to analyze purchasing behavior for:

- Buyer's response to a firm's advertising tactic which has a terrific effect on the company's success.

- The marketing idea stresses that a firm must develop a Marketing Mix which fulfils/gives energy to the clients, thus have to evaluate what, which, how and when the customers buy.

- Marketers can better anticipate exactly how customers are going to respond to advertising strategies.

Consumer buying behaviour includes 5 steps that a company should look after to attract the customer. They are:-

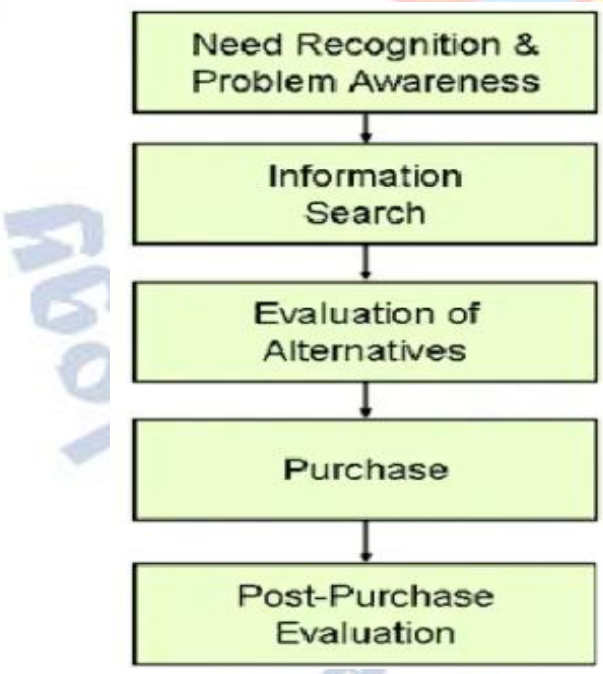

\section{Green consumers}

The Green customer is often referred to as one which uses eco-friendly behaviour or perhaps who buys green items with the traditional choices. Eco-friendly clients are certainly much more internally controlled because they believe that a private buyer could be great at environmental safety. So, they feel the performance of environmental protection should not stay to the government, business, environmentalists and scientists only; they as buyers likewise can have fun with a part. They are also less dogmatic and far more unbiased or perhaps tolerant toward items which are new

According to the use article of the European Union (Europe's customers), it is found that $10 \%$ of the customers realise eco-labels on the product at various stores and purchase them. Even though the businesses in the country progress with substantial rate in regards to the world, it is still not possible for us to claim they have arrived at the same level with regards to consumer awareness.

\section{Types of Green Consumers}

The study divides customers into four groups depending on the level of theirs of eco-consciousness. By watching consumer's purchasing behaviors, the study identified key buying motivations for each team and significant purchasing drivers. Based on the study, each team is distinct, both in the interest in green and its crucial values:

\section{True blue greens:}

This group of consumer is highly dedicated in using environmental friendly products. They even buy Green products knowing that the product cost is higher as compared to Normal products. They also try to avoid the use of product that are harmful for the environment. Along with this they also make contribution towards Environmental issues.

\section{Greenback Greens:}

This groups of consumer is similar to true blue. But, they are even willing to switch to eco-unfriendly products when faced with the issue of unavailability of the Green products and if the product is not coping with the new lifestyle.

\section{Sprouts:}

This group of consumer is not concerned about Environmental issues caused by various products and do no indulge in Green consumption. However, they are willing to buy Green products when these products are promoted to them in an convincing manner. They are the one who believes Environmental causes as a theory and don't believe in using this in a practice. On the basis of environmental needs \& standards they rank the companies. This makes as the most confusing one as they swing both ways.

\section{Grousers:}

This group of consumers do not believe they have the capability to effect any change. They 
are not committed towards any Environmental product. They do not believe in environmental causes and claim to have several reasons for not doing enough for the environment.

\section{Basic browns:}

These are business consumers who are concerned only with profits and may harm the environment too. They believe that they had nothing to do with the environment. It's just that their need should be fulfilled.

\section{Top Green Electronic companies}

Greenpeace has released its "Guide to Greener Electronics" for 2007. Here is its ranking of the world's biggest electronic gizmo producers:
a) Sony Ericsson-7.7/10
b) Samsung-7.7/10
c) Sony-7.3/10
d) Dell-7.3/10
e) Lenovo-7.3/10
f) Toshiba-7/10
g) LGE-7/10
h) Fujitsu-Siemens-7/10
i) Nokia-6.7/10
j) HP-6.7/10
k) Apple-6/10
1) Acer-5.7/10
m) Panasonic-5/10
n) Motorola-5/10
o) Sharp-4.7/10
p) Microsoft-2.7/10
q) Philips-2/10
r) Nintendo-0/10

\section{Top 10 Green Products}

a) Energy Saving TVs

b) LED Lights

c) Solar Water Heaters

d) Solar Panel Charging Cases

e) Eco-Friendly Verification Phone Apps

f) Green GPS Units

g) Solar Speakers

h) Green Power Outlets

i) Eco-Friendly Paper Shredder

j) Dryer Balls

\section{List of Green Product lead countries rank as per} EPEAT

\begin{tabular}{|l|l|l|l|l|l|}
\hline RANK & COUNTRY & GOLD & SILVER & BRONZ & MEDALS \\
\hline 1 & GERMANY & 3 & 0 & 0 & 3 \\
\hline 2 & INDIA & 1 & 2 & 1 & 4 \\
\hline 3 & DENMARK & 1 & 1 & 0 & 2 \\
\hline 4 & USA & 0 & 1 & 2 & 3 \\
\hline 5 & AUSTRALIA & 1 & 0 & 0 & 1 \\
\hline 5 & CHINA & 1 & 0 & 0 & 1 \\
\hline 5 & FALKLAND & 1 & 0 & 0 & 1 \\
\hline 5 & ISLAND & & & & \\
\hline 5 & FINLAND & 1 & 0 & 0 & 1 \\
\hline 5 & PAPAN & 1 & 0 & 0 & 1 \\
\hline 5 & URUGUAL & 1 & 0 & 0 & 1 \\
\hline
\end{tabular}

\section{REVIEW OF LITERATURE}

The concept of "Green Electronics" refers to resources used in the manufacturing of the Cell Phones, Computers, TV's and various other electrical devices which does not harm the Environment. For example, the plastic we see on the cable cords which is used in almost the electrical devices is usually burned off to reach the valuable copper within. As a result, this releases dangerous chemical which leads to the development of the Acid Rain and other environmental damage.

Although it might be inexpensive for the manufacturers to develop the products with the use of harmful toxic materials, Electronic companies are requested to eco- friendly resources or material for the production purpose.

Electronic Recyclers International (August 13, 2015) Over the last 2 years Tech community has expanded rapidly which led to consumption of Cell Phones, Computers and other electrical devices which are fancy and attractive and shows up every few months by the large no. of Americans. As a result this has led to the development of undesirable products. Due to this rapid development and updates has led to production of new products every few month, as a result of which this product is used as well as discarded when the new product arise giving rise to new environmental issue. E-waste contains various harmful materials which gives rise to the chemical which effects the environment. So as the electrical goods are discarded every few month, this give rise to E-waste which has started to fill up the landfill at a faster rate. Although, many recyclers like ERI have made various strategies to process E-waste, the Government is also giving pressure to various electronic companies to produce eco-friendly devices which can be reused and recycled.

MihaiIrimia-Vladuab (2014) mentioned that the primary goal of the research' Green' appliances: biocompatible and biodegradable is creating paths for the generation of human as well as eco-friendly electronic devices in common and additionally the integration of such electric circuits with living cells in certain.

Ms. Sukeshini Jadhav (2013) In "Electronic Waste: A Growing Concern in Today's Environment Sustainability" analysed the composition of e-waste, Indian and Global E-waste scenarios and various harmful materials present in the $\mathrm{E}$-waste and also finding various methods to identify harmful substances asserting the guidelines for 
the producers as well as making people aware about the best practices for better waste disposal.

Carrigan et al (2004),) individuals who purchase eco-friendly products is known as Green consumers. Although in addition to buying eco-friendly products and to recycling, Green consumption is also concerned with consuming goods with no harm to the environment.

Wasik (1996), Green products is also known as Eco-friendly Products. It is a product which causes • no risk to the environment and those which are $\bullet$ manufactured through Green technology. • Organisations, consumers, Government • Authorities usually identifies these products • through various Eco-labels or Green labels- Which shows that the products meet the Environment criteria which other product don't.

Kumar (2015), made an attempt in order to make people aware about the understanding of Eco-friendly products also known as Green Products. The study emphasize on eco-friendly marketing that the marketers should use as the consumers are willing to pay premium for it. Though Indian Government and businesses are making various efforts towards Green Products Lack of education and insufficient research work is a major setback.

A report by Renzai et al (2013), states that states that there's good perception of customers towards green. As per his report most of the respondents feels that Green can improve the health. $85.7 \%$ concept of Green can save the world as well as $79.3 \%$ feels really good to turn to green living.

\section{RESEARSCH METHODOLOGY}

\section{Methodology}

The word Methodology is produced from two word Meta and Hodos which together means a method. A method requires various strategies which includes various step to showcase the technique gathering information. In short a method is the way of accomplishing something.

\section{Structure of paper}

This report includes both qualitative as well as quantitative data. The data presented through tables and graphs is quantitative, whereas, theoretical analysis is qualitative.

\section{'Population' of the Seminar Paper}

People belonging to East and North India are taken into consideration.

\section{Collection Of Data}

The Research layout for the study was a descriptive style which describes the concept of
Green Electronics and consumer behaviour towards it. This research deals with the perception of consumer buying behaviour toward green electronics. The report is base on both Primary and Secondary data.

Primary data include various questionnaire distributed among 150 consumers in North and East India. 130 responses out of which was found useful for the study. Among 130 Responses:-

$21.5 \%$ were aged below 20

$35.4 \% \%$ were aged $\mathrm{b} / \mathrm{w} 21-30$

$24.6 \% \%$ were aged $\mathrm{b} / \mathrm{w} 31-40$

$16.9 \%$ were aged $\mathrm{b} / \mathrm{w}$ 41-50

$1.5 \%$ were aged above 50

The first part of questionnaire contained Yes as well as No as two possible responses. It inquired about the understanding of Green Electronics and its awareness among the consumers and their willingness to buy Green electronic goods. Then questionnaire inquired whether the consumer is willing to pay extra cost for purchasing such eco-friendly products. It also inquired about whether eco-friendly label gives satisfaction to them or not and whether they fell happy about purchasing a Green Electronics products or not. The consumer were also inquired about whether they think companies in future would prefer manufacturing Green electronic Goods rather than Normal electronic goods.

Secondary data: through various journals, articles, websites to form a strong literature review.

\section{Limitation}

Random sampling was used to collect the data and thus the results might not be generalized beyond the test frame. The responses of the sample may be biased as the research was done using Self reporting questionnaire. We can summaries our limitation of the research as follows:-

Respondents were at times reluctant to fill up the questionnaire.

- Lack of sufficient research documents on the subject.

- Limited time

- And the main limitation is the prevailing Covid -19 pandemic due to which interview is out of question

\section{OBJECTIVE OF THE STUDY}

1. To study the attitude of consumers regarding green electronics.

2. To study the purchase intentions of consumers regarding green electronics.

3. To study the factors that make consumers to buy green electronics. 


\section{ANALYSIS AND FINDINGS}

\section{ANALYSIS}

1.AGE

\begin{tabular}{|c|c|c|}
\hline \multicolumn{3}{|c|}{ Statistics } \\
\hline \multirow{2}{*}{$\mathrm{N}$} & Valid & 130 \\
\cline { 2 - 3 } & Missing & 0 \\
\hline \multirow{2}{*}{ Mean } & 2.4154 \\
\hline \multicolumn{2}{|c|}{ Median } & 2.0000 \\
\hline \multicolumn{2}{|c|}{ Mode } & 2.00 \\
\hline
\end{tabular}

\begin{tabular}{|c|c|c|c|}
\hline \multicolumn{1}{|c|}{} & Frequency & Percent \\
\hline \multirow{3}{*}{ Valid } & Below 20 & 28 & 21.5 \\
\cline { 2 - 4 } & $21-30$ & 46 & 35.4 \\
\cline { 2 - 4 } & $31-40$ & 32 & 24.6 \\
\cline { 2 - 4 } & $41-50$ & 22 & 16.9 \\
\cline { 2 - 4 } & Above 50 & 2 & 1.5 \\
\hline \multirow{2}{*}{} & Total & 130 & 100.0 \\
\hline
\end{tabular}

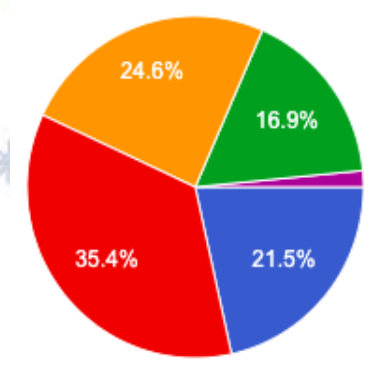

(The data shows that $21.5 \%$ of respondents were aged Below 20, 35.4\% were aged b/w 21-30, 24.6\% were aged $\mathrm{b} / \mathrm{w}$ were aged b/w 31-40, 16.9\% were aged $\mathrm{b} / \mathrm{w} 41-50$ and only $1.5 \%$ were $50-\mathrm{ABOVE}$. The Mode is 2 which Indicates that Most of the Respondents were aged b/w 21-30.)

\section{GENDER}

\section{Statistics}

\begin{tabular}{l|l|l}
$\mathrm{N}$ & Valid & 130 \\
\cline { 3 - 3 } & Missing & 0 \\
\hline Mean & & 1.2923 \\
\hline Median & & 1.0000 \\
\hline Mode & & 1.00
\end{tabular}

\begin{tabular}{|l|l|l|l|l|l|}
\hline \multicolumn{2}{|c|}{} & $\begin{array}{l}\text { Freque } \\
\text { ncy }\end{array}$ & $\begin{array}{l}\text { Perce } \\
\text { nt }\end{array}$ & $\begin{array}{l}\text { Valid } \\
\text { Percent }\end{array}$ & $\begin{array}{l}\text { Cumulat } \\
\text { ive } \\
\text { Percent }\end{array}$ \\
\hline $\begin{array}{l}\text { Val } \\
\text { id }\end{array}$ & Male & 92 & 70.8 & 70.8 & 70.8 \\
\cline { 2 - 6 } & $\begin{array}{l}\text { Fem } \\
\text { ale }\end{array}$ & 38 & 29.2 & 29.2 & 100.0 \\
\cline { 2 - 6 } & $\begin{array}{l}\text { Tota } \\
1\end{array}$ & 130 & $\begin{array}{l}100 . \\
0\end{array}$ & 100.0 & \\
\hline
\end{tabular}

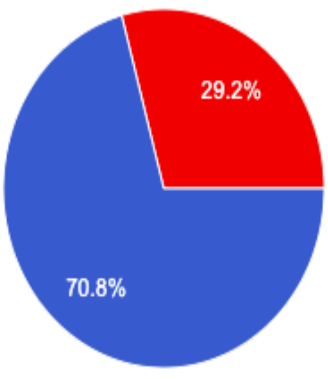

MALE

FEMALE
(The data represents that $70.8 \%$ were male and rest $29.2 \%$ were Female. The Mode is 1 which Indicates that most of the respondents were Male.)
3. Odiccupartion

3. OCCUPATION
Statistics

\section{Statistics}

Occupgtign

N $\quad 130^{2.1 .5}$

\begin{tabular}{r|l}
35.4 Missing & 056.9 \\
\hline Mean 24.6 & 1.58465 \\
\hline
\end{tabular}

\begin{tabular}{l|l} 
Median $_{5.9}$ & 2.0889 \\
\hline Mode & $2.000^{15.5}$ \\
\hline
\end{tabular}

\begin{tabular}{|c|c|c|c|c|c|}
\hline \multirow{2}{*}{\multicolumn{2}{|c|}{1.5}} & \multirow{2}{*}{\multicolumn{3}{|c|}{100.0}} & \multirow[b]{3}{*}{$\begin{array}{l}\text { Cumula } \\
\text { tive }\end{array}$} \\
\hline & & & & & \\
\hline & 100.0 & $\begin{array}{l}\text { Frequ } \\
\text { ency }\end{array}$ & $\begin{array}{l}\text { Perc } \\
\text { ent }\end{array}$ & $\begin{array}{l}\text { Valid } \\
\text { Percent }\end{array}$ & \\
\hline \multicolumn{2}{|c|}{ 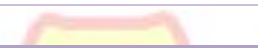 } & r & & & Percent \\
\hline \multirow{4}{*}{$\begin{array}{l}\text { Va } \\
\text { lid }\end{array}$} & Student & 55 & 42.3 & 42.3 & 42.3 \\
\hline & $\begin{array}{l}\text { Job/Busin } \\
\text { ess }\end{array}$ & 74 & 56.9 & 56.9 & 99.2 \\
\hline & $\begin{array}{l}\text { Housewife } \\
\text { / Retired }\end{array}$ & 1 & .8 & .8 & 100.0 \\
\hline & Total & 130 & $\begin{array}{l}100 . \\
0\end{array}$ & 100.0 & \\
\hline
\end{tabular}

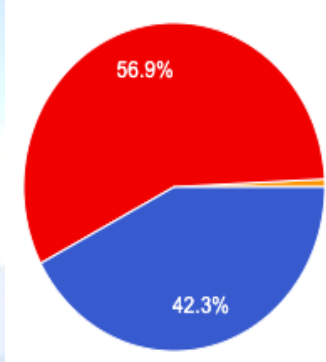

STUDENT

JOB/BUSINESS

HOUSEWIFE/RETIRED

The data represents that the $42.3 \%$ respondents were STUDENTS, $56.9 \%$ were doing JOB/BUSINESS, and rest .8\% were

HOUSEWIFE/RETIRED. The Mode is 2 which indicates that most of the respondent were doing Job or have Business.)

\section{EDUCATION}

\begin{tabular}{|l|l|l|}
\hline \multicolumn{2}{|l|}{ Statistics } & \multicolumn{2}{l|}{} \\
\hline $\mathrm{N}$ & Valid & 130 \\
\cline { 2 - 3 } & Missing & 0 \\
\hline Mean & 2.0615 \\
\hline Median & 2.0000 \\
\hline Mode & 2.00 \\
\hline
\end{tabular}




\begin{tabular}{|l|l|l|l|l|l|}
\hline \multicolumn{2}{|c|}{} & $\begin{array}{l}\text { Frequ } \\
\text { ency }\end{array}$ & $\begin{array}{l}\text { Perce } \\
\text { nt }\end{array}$ & $\begin{array}{l}\text { Valid } \\
\text { Percent }\end{array}$ & $\begin{array}{l}\text { Cumulat } \\
\text { ive } \\
\text { Percent }\end{array}$ \\
\hline $\begin{array}{l}\text { Val } \\
\text { id }\end{array}$ & $\begin{array}{l}\text { Intermedia } \\
\text { te }\end{array}$ & 13 & 10 & 10 & 10 \\
\cline { 2 - 6 } & $\begin{array}{l}\text { Graduatio } \\
\text { n }\end{array}$ & 96 & 73.8 & 73.8 & 83.8 \\
\hline & $\begin{array}{l}\text { Post-Grad } \\
\text { uation }\end{array}$ & 21 & 16.2 & 16.2 & 100.0 \\
\hline & Total & 130 & 100. & 100.0 & \\
\hline
\end{tabular}

(The data represents that, $48.5 \%$ of respondents earn less than 50,000 monthly, $36.2 \%$ of respondents earn between 50,000 and 1,00,000 i.e. they fall under Middle Income Group, 15.4\% respondents earn More than 1,00,000 i.e. they fall under Higher Income Group. And as shown in the Occupation Table $42.3 \%$ were students so this doesn't means that $48.5 \%$ of respondents who earns less than 50,000 falls under Lower Income Group. The Mode is 1 which indicates that most of the respondents earn Less than 50000.)

\section{ARE YOU AWARE OF GREEN ELECTRONICS?}
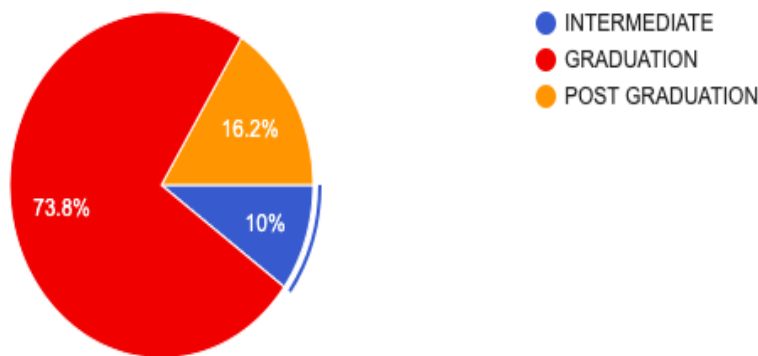

( The data represents that $10 \%$ of respondents falls under Intermediate Level, 73.8\% have Graduation Degree, and $16.2 \%$ are postgraduate. This means that $90 \%$ of the respondents have 15 or more years of education. The Mode is 2 which indicates that most of the respondents were Graduates.)

\section{MONTHLY INCOME}

\begin{tabular}{l|l|l}
\hline \multicolumn{2}{l|l}{ Statistics } & \\
\hline $\mathrm{N}$ & Valid & 130 \\
\cline { 2 - 3 } & Missing & 0 \\
\hline Mean & 1.6769 \\
\hline Median & 2.0000 \\
\hline Mode & 1.00 \\
\hline
\end{tabular}

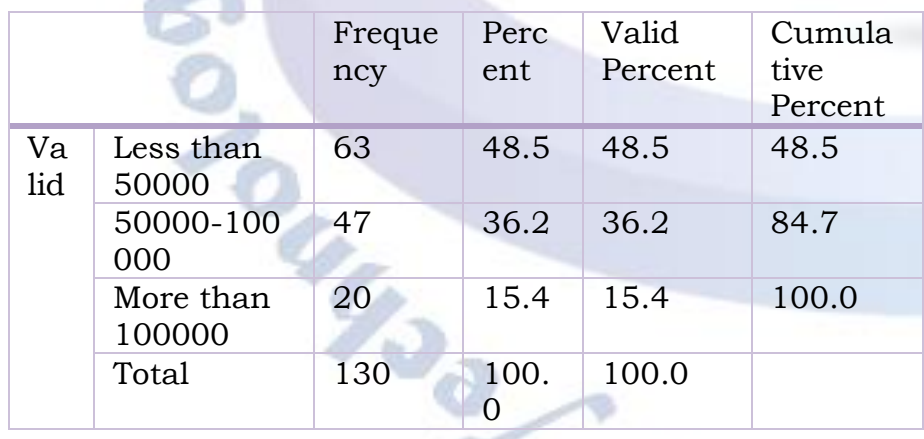

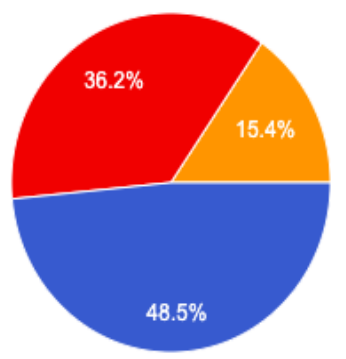

LESS THAN 50,000

$50,000-1,00,000$ MORE THAN $1,00,000$

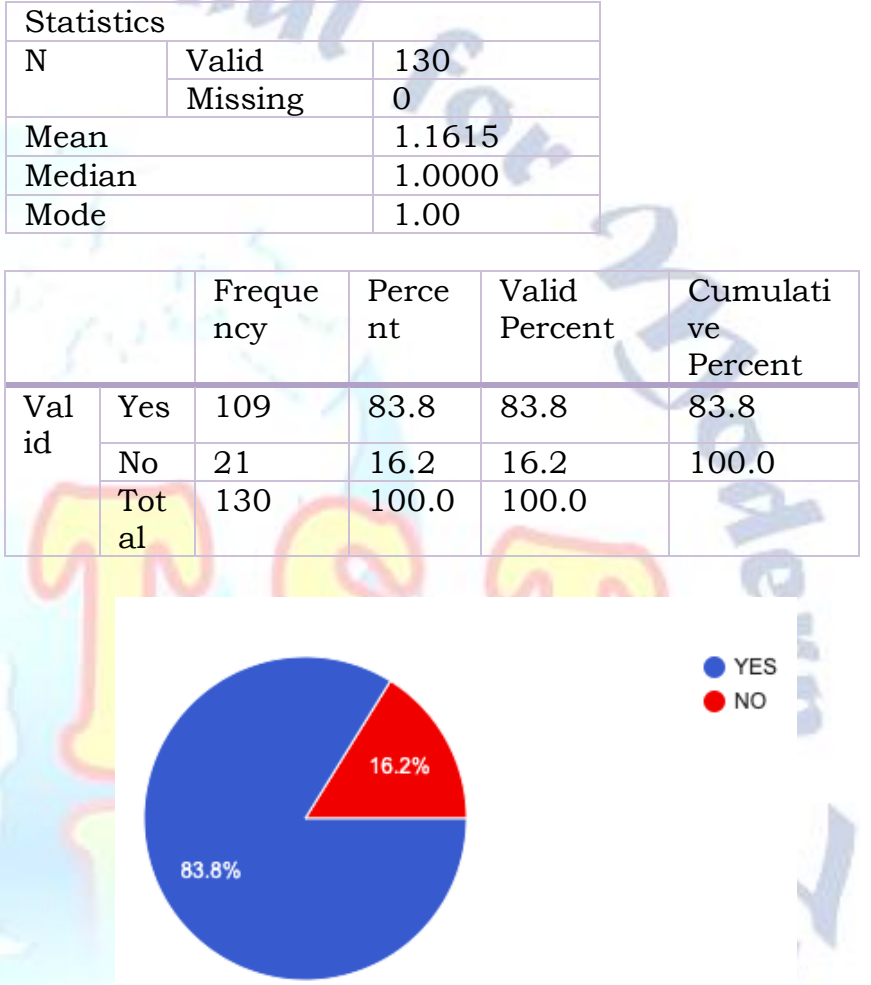

(When people were asked if they are aware about Green Electronics, $83.8 \%$ said that they were aware about it where as other $16.2 \%$ said no. The Mode is 1 which indicates that most of the respondent said Yes.)

\begin{tabular}{|c|c|c|c|c|c|}
\hline \multicolumn{5}{|c|}{ GREEN? } & \\
\hline \multicolumn{5}{|c|}{ Statistics } & \\
\hline \multirow{2}{*}{\multicolumn{2}{|c|}{$\mathrm{N}$}} & Valid & \multicolumn{2}{|l|}{130} & \\
\hline & & Missing & \multirow{2}{*}{\multicolumn{2}{|c|}{$\begin{array}{l}0 \\
1.1462\end{array}$}} & \\
\hline \multirow{2}{*}{\multicolumn{3}{|c|}{$\begin{array}{l}\text { Mean } \\
\text { Median }\end{array}$}} & & & \\
\hline & & & \multicolumn{2}{|c|}{$\begin{array}{l}1.1462 \\
1.0000\end{array}$} & \\
\hline \multicolumn{3}{|c|}{ Mode } & \multicolumn{2}{|c|}{1.00} & \\
\hline & & $\begin{array}{l}\text { Freque } \\
\text { ncy }\end{array}$ & $\begin{array}{l}\text { Perce } \\
\text { nt }\end{array}$ & $\begin{array}{l}\text { Valid } \\
\text { Percent }\end{array}$ & $\begin{array}{l}\text { Cumulati } \\
\text { ve } \\
\text { Percent }\end{array}$ \\
\hline \multirow{3}{*}{$\begin{array}{l}\text { Val } \\
\text { id }\end{array}$} & Yes & 111 & 85.4 & 85.4 & 85.4 \\
\hline & No & 19 & 14.6 & 14.6 & 100.0 \\
\hline & $\begin{array}{l}\text { Tot } \\
\text { al }\end{array}$ & 130 & 100.0 & 100.0 & \\
\hline
\end{tabular}




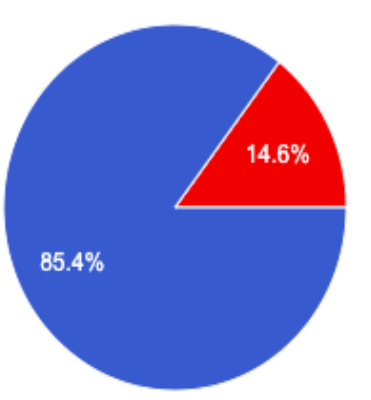

(when people were asked if they are aware about companies going , $85.4 \%$ said that they were aware about it where as other $14.2 \%$ said no. The Mode is 1 which indicates that most of the respondent said Yes.)

9.DO YOU PREFER GREEN ELECTRONIC THAN NORMAL ELECTRONIC PRODUCTS?

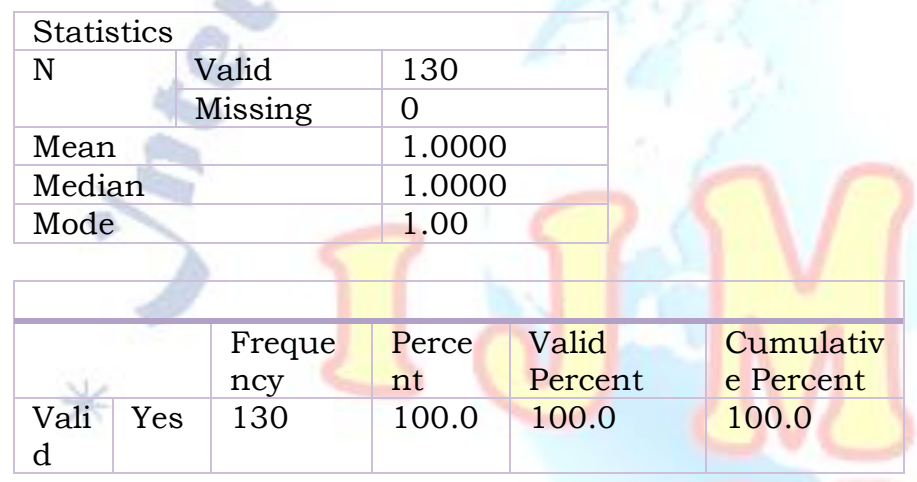

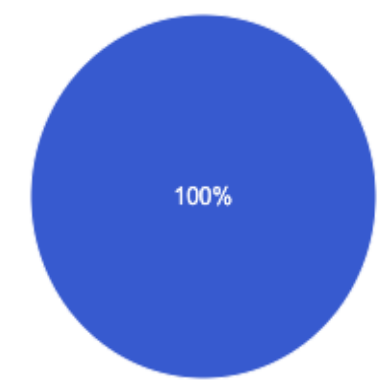

(When people were asked if they would prefer Green Electronics products or not, 100\% said yes. The Mode is 1 which indicates that most of the respondent said Yes.)

\section{ARE YOU WILLING TO BEAR EXTRA COST FOR} GREEN ELECTRONIC PRODUCTS?

\section{Statistics}

\begin{tabular}{l|l|l}
\multirow{2}{*}{$\mathrm{S}$} & Valid & 130 \\
\cline { 3 - 3 } & Missing & 0 \\
\hline Mean & & 1.1385 \\
\hline Median & & 1.0000 \\
\hline Mode & 1.00 \\
\hline
\end{tabular}

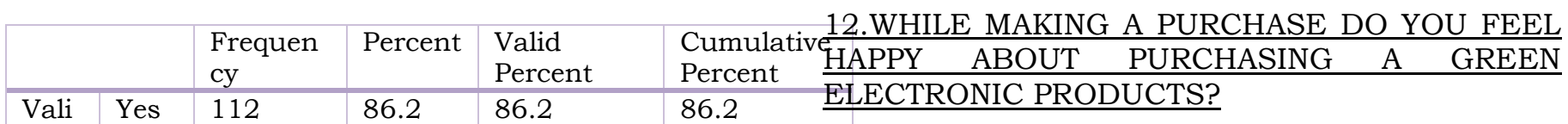

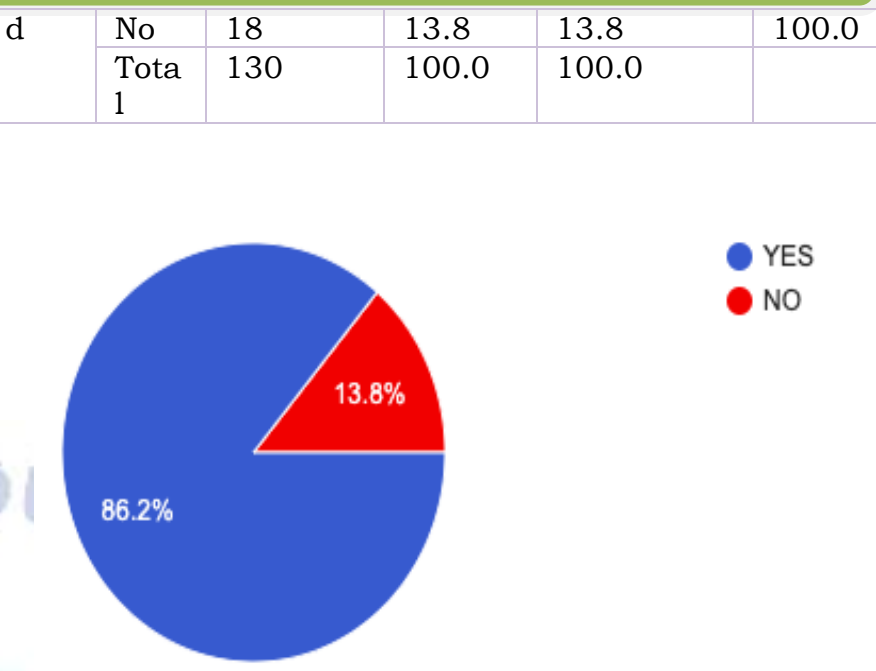

(when people were asked if they are willing to pay more for Green Electronic products $86.2 \%$ said yes where as other $13.8 \%$ said no. The Mode is 1 which indicates that most of the respondent said Yes.)

11.DO ECO-LABELS GIVES YOU SATISFACTION THAT THE PRODUCT IN QUESTION IS ACTUALLY GREEN?

Statistics

\begin{tabular}{l|l|l|}
\hline $\mathrm{N}$ & Valid & 130 \\
\hline & Missing & 0 \\
\hline Mean & & 1.0385 \\
\hline Median & & 1.0000 \\
\hline Mode & 1.00 \\
\hline
\end{tabular}

\begin{tabular}{|l|l|l|l|l|l|}
\hline \multicolumn{2}{|c|}{} & $\begin{array}{l}\text { Freque } \\
\text { ncy }\end{array}$ & $\begin{array}{l}\text { Perce } \\
\text { nt }\end{array}$ & $\begin{array}{l}\text { Valid } \\
\text { Percent }\end{array}$ & $\begin{array}{l}\text { Cumulati } \\
\text { ve } \\
\text { Percent }\end{array}$ \\
\hline \multirow{2}{*}{$\begin{array}{l}\text { Val } \\
\text { id }\end{array}$} & Yes & 125 & 96.2 & 96.2 & 96.2 \\
\cline { 2 - 6 } & No & 5 & 3.8 & 3.8 & 100.0 \\
\cline { 2 - 6 } & $\begin{array}{l}\text { Tot } \\
\text { al }\end{array}$ & 130 & 100.0 & 100.0 & \\
\hline
\end{tabular}

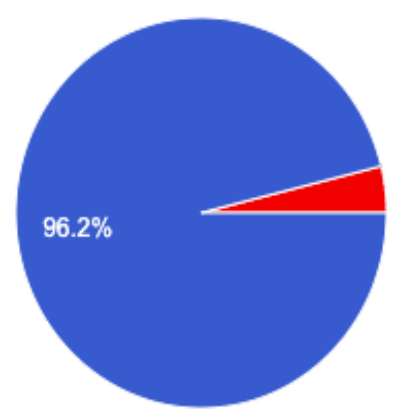

YES NO

(When people were asked whether Eco-labels satisfies them that the product in question is actually Green or not, $96.2 \%$ said yes whereas other $3.8 \%$ said no. The Mode is 1 which indicates that most of the respondent said Yes.) 


\begin{tabular}{|l|l|l|}
\hline \multicolumn{2}{|l|}{ Statistics } & \multicolumn{2}{l|}{} \\
\hline \multirow{2}{*}{$\mathrm{N}$} & Valid & 130 \\
\cline { 2 - 3 } & Missing & 0 \\
\hline Mean & 1.0077 \\
\hline Median & 1.0000 \\
\hline Mode & 1.00 \\
\hline
\end{tabular}

\begin{tabular}{|l|l|l|l|l|l|}
\hline \multicolumn{2}{|c|}{} & $\begin{array}{l}\text { Freque } \\
\text { ncy }\end{array}$ & $\begin{array}{l}\text { Perce } \\
\text { nt }\end{array}$ & $\begin{array}{l}\text { Valid } \\
\text { Percent }\end{array}$ & $\begin{array}{l}\text { Cumulati } \\
\text { ve } \\
\text { Percent }\end{array}$ \\
\hline \multirow{2}{*}{$\begin{array}{l}\text { Val } \\
\text { id }\end{array}$} & Yes & 129 & 99.2 & 99.2 & 99.2 \\
\cline { 2 - 6 } & No & 1 & .8 & .8 & 100.0 \\
\cline { 2 - 6 } & $\begin{array}{l}\text { Tot } \\
\text { al }\end{array}$ & 130 & 100.0 & 100.0 & \\
\hline
\end{tabular}

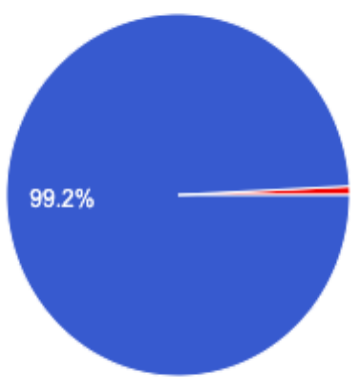

(When people were asked while making purchase whether they feel happy about purchasing Green Electronic Products or not, 99.2\% said Yes whereas other 0.8 said no. The Mode is 1 which indicates that most of the respondent said Yes.)

13. DO YOU THINK IT IS DIFFICULT FOR THE COMPANIES TO MANUFACTURE GREEN ELECTRONICS?

\begin{tabular}{|l|l|l|}
\hline \multicolumn{2}{l|}{ Statistics } & \\
$\mathrm{N}$ & Valid & 130 \\
\hline Mean & Missing & 0 \\
\hline Median & 2.8154 \\
\hline Mode & 3.0000 \\
\hline
\end{tabular}

\begin{tabular}{|c|c|c|c|c|c|}
\hline & & $\begin{array}{l}\text { Frequ } \\
\text { ency }\end{array}$ & $\begin{array}{l}\text { Perc } \\
\text { ent }\end{array}$ & $\begin{array}{l}\text { Valid } \\
\text { Percent }\end{array}$ & $\begin{array}{l}\text { Cumula } \\
\text { tive } \\
\text { Percent }\end{array}$ \\
\hline \multirow{7}{*}{$\begin{array}{l}\text { Va } \\
\text { lid }\end{array}$} & Strongly & 16 & 12.3 & 12.3 & 12.3 \\
\hline & Disagree & & & & \\
\hline & Disagree & 34 & 26.2 & 26.2 & 38.5 \\
\hline & Neutral & 43 & 33.1 & 33.1 & 71.6 \\
\hline & Agree & 33 & 25.4 & 25.4 & 97 \\
\hline & $\begin{array}{l}\text { Strongly } \\
\text { Agree }\end{array}$ & 4 & 3.1 & 3.1 & 100.0 \\
\hline & Total & 130 & $\begin{array}{l}100 . \\
0\end{array}$ & 100.0 & \\
\hline
\end{tabular}

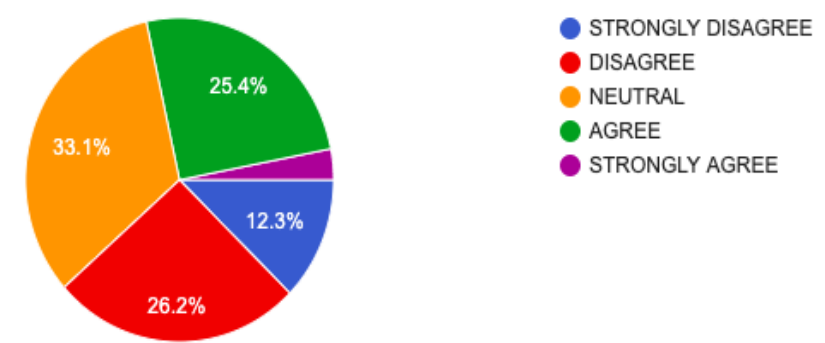

(When people were asked what they think, is it difficult for the companies to manufacture Green electronic Products or not, $12.3 \%$ Strongly agreed, 26.2\% Disagreed, 33.1\% were Neutral, 25.4

Agreed, 3.1\% Strongly Agreed. The Mode is 3 which indicates that most of the Respondents were

Neutral that it could be or could be not difficult for the companies to Manufacture Green Electronic Products.)

14.DO YOU THINK IN FUTURE COMPANIES WOULD PREFER MANUFACTURING GREEN ELECTRONIC PRODUCTS RATHER THAN NORMAL ELECTRONIC PRODUCTS?

\section{Statistics}

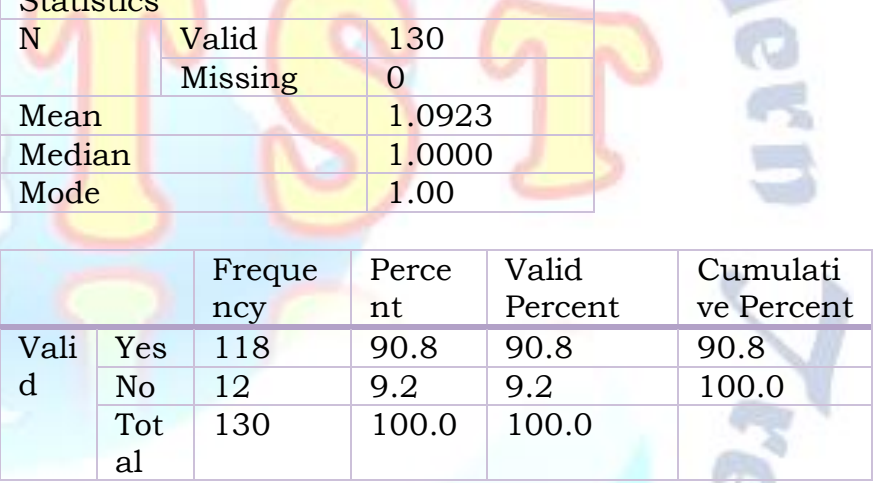

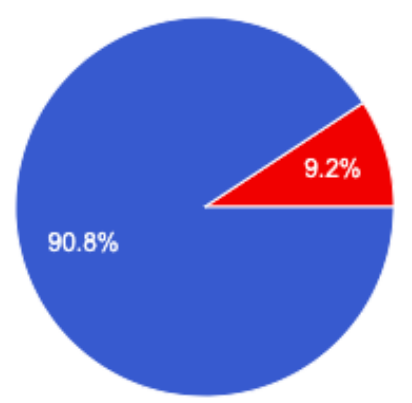

(When people were asked what they think whether in future companies would prefer manufacturing Green Electronic Products or not, 90.8\% said yes where as $9.2 \%$ said no. The Mode is 1 which indicates that most of the respondent said Yes.)

15.DO YOU THINK GREEN COMPANIES HAVE COMPETITIVE ADVANTAGE OVER NORMAL COMPANIES? 
Statistics

\begin{tabular}{|l|l|l|}
\hline $\mathrm{N}$ & Valid & 130 \\
\cline { 3 - 3 } & Missing & 0 \\
\hline Mean & & 1.1154 \\
\hline Median & & 1.0000 \\
\hline Mode & 1.00 \\
\hline
\end{tabular}

\begin{tabular}{|l|l|l|l|l|l|}
\hline \multicolumn{2}{|c|}{} & $\begin{array}{l}\text { Freque } \\
\text { ncy }\end{array}$ & $\begin{array}{l}\text { Percen } \\
\mathrm{t}\end{array}$ & $\begin{array}{l}\text { Valid } \\
\text { Percent }\end{array}$ & $\begin{array}{l}\text { Cumulati } \\
\text { ve } \\
\text { Percent }\end{array}$ \\
\hline $\begin{array}{l}\text { Val } \\
\text { id }\end{array}$ & Yes & 115 & 88.5 & 88.5 & 88.5 \\
\cline { 2 - 6 } & No & 15 & 11.5 & 11.5 & 100.0 \\
\cline { 2 - 6 } & $\begin{array}{l}\text { Tot } \\
\text { al }\end{array}$ & 130 & 100.0 & 100.0 & \\
\hline
\end{tabular}

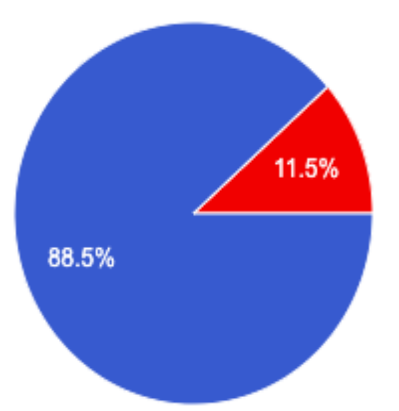

(When people were asked what they think whether Green Companies have competitive advantage over Normal Companies or not, $88.5 \%$ said yes whereas $11.5 \%$ said no. The Mode is 1 which indicates that most of the respondent said Yes.)

\section{FINDINGS}

As per the survey conducted:

- people in North and East India are aware of what Green Electronics is.

- Consumers are willing to buy Green electronic products/ Eco-friendly goods.

- Consumers are even willing to pay extra cost for Green electronic goods.

- Companies should prefer manufacturing Green Electronics products for better tomorrow.

- Eco-labels on the product does satisfy the consumers that the product is actually Green i.e. eco-friendly and the do get motivated to purchase eco-friendly goods.

- When people purchase/consume goods they are mostly concerned about environment. Consumer is king now. The know about everything and wants to know about everything. They are much sensible towards the product they are purchasing. So companies and government should make constant efforts towards awareness and understanding of eco-friendly goods.
- $\quad 85.4$ of people are aware of companies developing Green products whereas other said no.

- It was found that Perception of consumer regarding Green Electronic was positive.

- As far as Green Electronics is concerned, Government should take more initiatives to promote Green electronics and measures to recycle E-waste.

- Top companies Like Wipro, HP, Sony, etc have taken various initiative to promote Green Electronics and thus reusing the old Electronic Goods.

- As far as Green product is concerned India is ranked second in the world.

\section{CONCLUSION AND SUGGESTION}

In the current scenario development is taking place at a greater rate and Electronic goods play an important role in such development, which is degrading the environment at a rapid rate due to the E-waste generated through it. Hence, it is necessary to take initiatives now rather than regretting later. Without a doubt, Electronic good like Computer, Smartphone, etc have made our lives easier in an outstanding manner and has opened up new opportunities for all of us, but this comes with a great risk to Earth's Resources due to growing amount of E-waste. Green electronic can lower the risk of E-Waste to the environment and can ensure healthy future for the upcoming generation. Perception can make a huge difference. As per the survey conducted, consumers have a positive perception about Green Electronics. They are even willing to pay extra cost for the green electronic products to safeguard the environment. But the companies and government really do need to make more initiative for recycling E-waste and spread more awareness among the public for the same. This can be possible by developing Health and Safety Standards E.g. raising funds for environmental causes. Public Private Partnership (PPP) should also be introduced where consumer, govt. and companies work together to solve the problem. There is also one way where govt. should provide incentive to those who take various measures to develop Green Electronic Products and also promote marketing of the same through Authorised Certificate. There are also 5 Sustainable Green Initiatives That India Can Learn From Sweden.
1. SUSTAINABLE PUBLIC TRANSPORT
2. INVESTING IN GREEN TECH 


\section{SUSTAINABLE HOUSING \\ 4. SUSTAINABLE LIFESTYLE \\ 5. GREEN AGRICULTURE}

Companies should start making eco-friendly goods which can be recycled and can be used for the longest time(large lifecycle) and which has less power consumption. Government should start make use of L.E.D'S for the street lights so that the electricity consumption consumption is reduced. Consumer should also make some efforts towards the society and make people in the surrounding aware about the eco-friendly goods.

\section{REFERENCES}

[1] R. Maheshwari. (2014). A Study On The Impact Of Green Advertising On The Consumers Purchase Intention Of Green Products With Reference To Coimbatore India. Retrieved from http://hdl.handle.net/10603/244477

[2] Morshed Abdullah. (2014). Consumer Purchasing Behavior Towards Green Product. Retrieved from https://www.academia.edu/8413233/Consumers_Purcha sing_Behaviour_towards_Green_Product

[3] Major $r$ rajasekaran1 and $n$ gnanapandithan2. (2013). A Study on Green Product and Innovation for Sustainable Development . Retrieved from https://www.ripublication.com/gimbs_spl/gjmbsv3n6_09 .pdf

[4] Mrinalini singh. (, ). Consumers are often mislead sometimes because of confusing name, shape, size and description and sometimes due to their own negligence This article is an attempt to tell the rights and powers which have been given to consumers and recourse available to them if mislead. [Weblog]. Retrieved from http://www.legalservicesindia.com/article/1028/Consum er-the-King.html

[5] Electronics recyclers international. (2015, 1 September). What Does 'Green Electronics' Mean?. [Weblog]. Retrieved from

https://nerc.org/news-and-updates/blog/nerc-blog/2015 109/01/what-does-green-electronics-mean

[6] Shopify. (n.p.). Green Marketing. Retrieved from https://www.shopify.in/encyclopedia/green-marketing

[7] Green electronic council. (n.p.). GEC and EPEAT OVERVIEW. Retrieved from

https://greenelectronicscouncil.org/

[8] Make In India. (n.p.). 5 Sustainable Green Initiatives That India Can Learn From Sweden. Retrieved from https://www.makeinindia.com/article/-/v/5-sustainablegreen-initiatives

[9] Dr Raghupathy, Mrs Kruger, Dr. Chaturvedi, Dr. Arora, Mr Henzler . (2019). E-Waste Recycling In India - Bridging The Gap Between The Informal And Formal Sector. Retrieved from

http://greene.gov.in/wp-content/uploads/2018/01/Krue ger.pdf

$\begin{array}{llll}\text { [10] John. } & \text { P. } & \text { Mello } & \text { Jr. (2012, }\end{array}$ Nov). . [Weblog]. Retrieved from https://www.pcworld.com/article/2014720/wipro-hp-top -greenpeace-list-of-green-electronics-companies.html

[11] SmartCompany . (2007). Top 10 green electronics companies. Retrieved from

https://www.smartcompany.com.au/technology/emergin g-technology/top-10-green-electronics-companies/
[12] Kumar_Chinnas. (2010). Green

Electronics. Retrieved from

https://www.scribd.com/presentation/26657230/GreenElectronics

[13] Prachi Trivedi, Dr. Meghna Sharma. (2018, January). An Empirical Study on the Perception of Consumers about Green Products in Delhi. [Weblog]. Retrieved from https://www.researchgate.net/publication/324526202_A n_empirical_study_on_the_perception_of_consumers_abou t_green_products_in_Delhi

[14] Ayeshasweet. (2011). Green Electronics. Retrieved 21 May, 2020, from

https://www.scribd.com/presentation/65202525/GreenElectronics

[15] Essays, UK. (November 2018). The Cause Effect Of Green Electronic Products Marketing Essay. Retrieved from https://www.ukessays.com/essays/marketing/the-cause -effect-of-green-electronic-products-marketing-essay.php? $\underline{\text { vref }=1}$
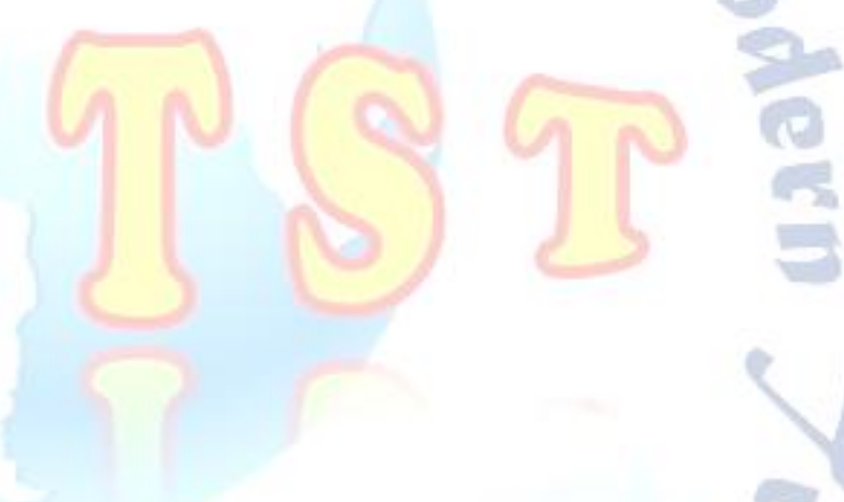